\title{
E-Governance in Rural India: Need of Broadband Connectivity Using Wireless Technology
}

\author{
Kalpana Chaudhari, Upena Dalal, Rakesh Jha \\ Department of Electronics Engineering, Sardar Vallabhbhai National Institute of Technology, Surat, India. \\ Email: isdrklc@hotmail.com, udd@eced.svnit.ac.in,jharakesh.45@gmail.com
}

Received January $16^{\text {th }}, 2011$; Revised February 27 ${ }^{\text {th }}, 2011$; Accepted April $7^{\text {th }}, 2011$.

\begin{abstract}
The Information and Communication Technologies play an important role in rural development. The Empowerment of rural communities is crucial for the development of the rural region. Bringing the people in the rural region in the mainstream of the digital technologies to access and adopt modern technologies is a major concern now. Rural Development implies both, the economic development of the people and greater social transformation using electronic governance (e-governance). In order to provide the rural people in Maharashtra with better prospects and opportunities for economic development, agricultural development and management, marketing management, increased participation of rural people in usage and adoption of information and communication technologies (ICTs) is envisaged. This paper aims to explore the nature, role and relevance of the Electronic/Digital Governance using ICTs and wireless technologies for agriculture and rural development in the rural regions. It also aims to study the impact of e-governance on rural development and methods for improving local environmental governance having regard particularly to the range of interests and actors involved in e-governance. The paper examines the current status of electronic governance in Jalgaon district in India. It focuses on development of the model using ICTs/wireless technologies for e-governance of Jalgaon district in Maharashtra state, India.
\end{abstract}

Keywords: E-Governance, WiMAX, Application of Information Technology, Wireless Technology

\section{Introduction}

Connectivity is vital in business and society in India. There is rapid growth in information technology related business in India. But only a meagre percentage of Indians have internet connection at their residence. India has more than 9000 internet cafes having uninterrupted internet access enabling communication and interaction with other actors in e-governance through ICTs and wireless technologies such as, e-mail, audio or video chat etc. It also enables utilization of the various public services to collect the information about education opportunities, to search jobs for seeking employment etc by browsing the internet. Indians are generally enthusiastic about the Internet. With the lack of physical connectivity or telecommunication infrastructure, unaffordable cost and lack of ready accessibility to broadband technologies only few can use the Internet. Mostly rural India is lagging in development, education, health, entertainment services and the general living standard due to lack of Government support in creating ICT and Wireless infrastructure to reach rural masses. India is a land of geo- graphical diversities. There is comprehensive wired communication infrastructure in place today. WiMAX connectivity could play major role in improving the quality of public services and could bring substantial improvement in rural areas. Based on the IEEE 802.16 standard, the WiMAX (Worldwide Inter-operability for Microwave Access) is a telecommunications technology that provides wireless transmission of data using a variety of transmission modes, from point-to-multipoint links to portable and fully mobile internet access". The WiMAX is supported by the WiMAX forum, which is a non-profit organization formed to promote the adoption of WiMAX compatible products and services. WiMAX is a very promising technology with many key features over other wireless technologies. WiMAX is also known as wireless broadband. IEEE 802.16 is the standard for WiMAX. IEEE 802.16d-2004 is known as fixed WiMAX and IEEE 802.16e-2005 is known as mobile WiMAX.

\section{We Must Get Wireless in Rural Areas}

Despite the advantages of wireless alternatives in rural 
India, many rural areas are still without wireless access. Sometimes this is due simply to limitations of technology. Residences can be tens of miles apart in rural areas, making it difficult to propagate a signal to each home around the base station. The fact that homes are so sparse in rural areas also hinders companies from making the investments needed to supply rural areas with quality Internet service, even if technology exists to make this possible. As one can see from the illustration of Figure 1 with few potential customers in rural areas and so many packed closely together in cities, it is much more profitable to supply service to the densely populated areas rather than the spread-out farmers who would love to have the service that others enjoy. But, there are a few companies who recognize the technology needs of rural India and seek to fill them.

\section{The Benefits of Wireless Internet Access}

India is increasingly embracing wireless technologies. Cellular phones based on various wireless technologies have revolutionised telecommunication in India. Whereas the growth of fixed-line subscribers has slowed over the past several years, cellular usage has sky rocketed, nearly doubling in 2003 and growing by 159 percent so far in 2004, with 1.4 million new subscribers added every month. But these cellular technologies have not been sufficiently applied to deliver the broadband data connectivity to households in rural area due to high both cost and complexity. Yet, India needs a way to provide widespread Internet access. With widespread wireless broadband facilities, the Indian information technology (IT) industry would grow beyond cities reaching out to the rural populace. Students in rural areas could videoconference with educators across the country, and entertainment programs could be telecast to remote and otherwise unreachable areas along with Internet telephony services, using technologies like Voiceover Internet Protocol (VoIP). Improved communication could bring remote villages into the mainstream world economy. Information access could speed rural productivity and the faster communication between producers and suppliers would fuel greater demand for Indian products.

\section{The WiMAX Vis-A-Vis Other Cellular Technologies}

WiMAX promises to provide high-speed wireless cost effective connectivity more easily than current cellular technologies and it offers the scalability to deliver affordable broadband access across India. With the potential extendibility of wireless infrastructure to provide portable and mobile device support in future, WiMAX offers additional advantages for developing economies globally, such as that of India that do not have wide-

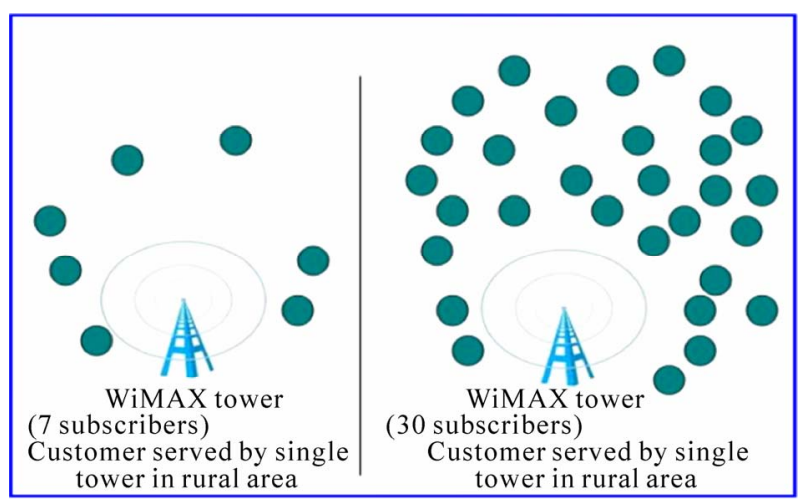

Figure 1. WiMAX scenario in urban and rural usage.

spread broadband technologies already in place. Tables 2 and $\mathbf{3}$ show the comparison with different wireless options for rural areas.

\section{Role of WiMAX in E-Governance in Rural India}

The Empowerment of Rural communities is crucial for the development of Rural India. Bringing the rural people into the mainstream of the digital technologies is a major concern now. Rural Development implies both the economic development of the people and social transformation using e-governance. In order to provide the rural people with better prospects and opportunities for economic development, increased participation of rural people in electronic governance through information and communication technologies are envisaged. In near future, rural population is likely to increase with further increase in poverty aggravating social, economic and environmental problems. Due to these problems, management of different services, natural resources and financial resource mobilization in rural areas, it would be necessary to study the application of e-governance using Information and Communication Technologies (ICTs)/ wireless technologies for its economic development. This paper studies the case of Jalgaon district located in Maharashtra state in India. The location is shown in Figure 3 Jalgaon district has 15 Talukas, 1498 villages and 767 Grampanchayats. The geographical information of Jalgaon district is given in Table 1. The WiMAX interconnectivity between the district head quarters (DHQ) and the 15 Taluka head quarters (THQ) enables them to access the information. It is further desirable that all villages in the district too be able to access the information. The village panchayat would establish Grampancahyat Knowledge Centre (GKC) to coordinate between the rural citizen, DHQ and THQ using WiMAX technology to make available the public services in all sectors. WiMAX model and e-governance models are shown in Figures 2 and $\mathbf{4}$ respectively. The model is designed to 
Table 1. Geographical information of Jalgoan district.

\begin{tabular}{ll}
\hline Geographical Area & $11,765 \mathrm{SqKm}$ \\
Jalgaon City & $68.78 \mathrm{Sqkm}$ (Source_Jalgaon City Municipal Corporation) \\
Crop Cultivation Area & 180,100 Hectare \\
Taluka/Tahsil in Jalgaon District & 15, Jalgaon, Jamner, Erandol, Dharangaon, Bhusaval, Bodwad, \\
& Yaval, Raver, MuktaiNagar, Amalner, Chopda, Parola, Pachora, \\
Total Villages, Cities and Places in Jalgaon District & 1498 \\
Total Number of Gram Panchayats in Jalgaon District & 787 (as per Election Commission's statistics—-01/05/2005) \\
Per Capita Income (at Current Prices) & Rs. 2666 \\
Population & $36,79,936$ \\
Growth Rate & Around 1.6\% per year \\
Male & $19,04,437$ \\
Female & $17,75,499$ \\
Male-Female Ratio & 932 female to 1000 male \\
Languages Spoken & Marathi, Hindi and English \\
Population Density (per SqKm) & 313 \\
Literacy (as per Census 2001) & $76.06 \%$ (Male—86.53\%, Female—64.95\%) \\
Computer Literacy & $57 \%$ \\
Computer Usage Ratio & 47 per 100 \\
\hline & \\
\hline
\end{tabular}

Table 2. Comparisons of rural wireless options.

\begin{tabular}{ccc}
\hline Technology & Data Rate & Coverage $^{* * *}$ \\
\hline Wi-Fi & 11 or $50 \mathrm{MBps}<=200 \mathrm{Mbps}^{*}$ & $100-1000 \mathrm{ft}<10 \mathrm{Km}$ \\
WiMAX & $<=70 \mathrm{Mbps}$ & $<=50 \mathrm{Km}$ \\
Satellite & $256 \mathrm{Kbps}-15 \mathrm{Mbps}$ & $40 \%$ of earth \\
Balloons & Unsure & 40 cell towers \\
\hline
\end{tabular}

${ }^{*}$ Wi-Fi typically ha a rate of 11 or 54 Mbps (802.11a, b, g) but rates can get as high as $200 \mathrm{Mbps}$ for $802.11 \mathrm{n} ;{ }^{* *}$ Coverage range of a single tower or device. For $\mathrm{WiFi}$, one source cites ranges only to $100 \mathrm{ft}$ while another gives a range of $\mathrm{Kms}$.

Table 3. Comparison of WiMAX standards.

\begin{tabular}{|c|c|c|c|c|}
\hline & IEEE 802.16-2001 & IEEE 802.16a & IEEE 802.16d-2004 & IEEE 802.16e-2005 \\
\hline Completed & Dec 2001 & Jan 2003 & Sept 2004 & Dec 2005 \\
\hline Spectrum & $10-66 \mathrm{GHz}$ & $2-11 \mathrm{GHz}$ & $2-11 \mathrm{GHz}$ & $2-11 \mathrm{GHz}$ \\
\hline $\begin{array}{l}\text { Propagation/Channel } \\
\text { Condition }\end{array}$ & LOS & NLOS & NLOS & NLOS \\
\hline Bit Rate & $\begin{array}{c}\text { Up to } 134 \text { Mbps } \\
\text { (28 MHz channelization) }\end{array}$ & $\begin{array}{c}\text { Up to } 75 \mathrm{Mbps} \\
\text { (20 MHz channelization) }\end{array}$ & $\begin{array}{c}\text { Up to } 75 \mathrm{MHz} \\
\text { (20 MHz channelization) }\end{array}$ & $\begin{array}{c}\text { Up to } 15 \mathrm{Mbps} \\
\text { (5 MHz channelization) }\end{array}$ \\
\hline Modulation & $\begin{array}{c}\text { QPSK-16-QAM } \\
\text { (Optional in UL) } \\
\text { 64-QAM } \\
\text { (Optional) }\end{array}$ & $\begin{array}{c}\text { BPSK, QPSK } \\
\text { 16-QAM } \\
\text { 64-QAM } \\
\text { 256-QAM } \\
\text { (Optional) }\end{array}$ & $\begin{array}{c}256 \text { Subscriber } \\
\text { OFDM, BPSK } \\
\text { QPSK, } \\
\text { 16-QAM } \\
\text { 64-QAM } \\
\text { 256-QAM }\end{array}$ & $\begin{array}{c}\text { Scalable } \\
\text { OFDMA, QPSK } \\
\text { 16-QAM } \\
\text { 64-QAM } \\
\text { 256-QAM } \\
\text { (Optional) }\end{array}$ \\
\hline Mobility & Fixed & Fixed & Fixed/Nomadic & Portable/Mobile \\
\hline
\end{tabular}




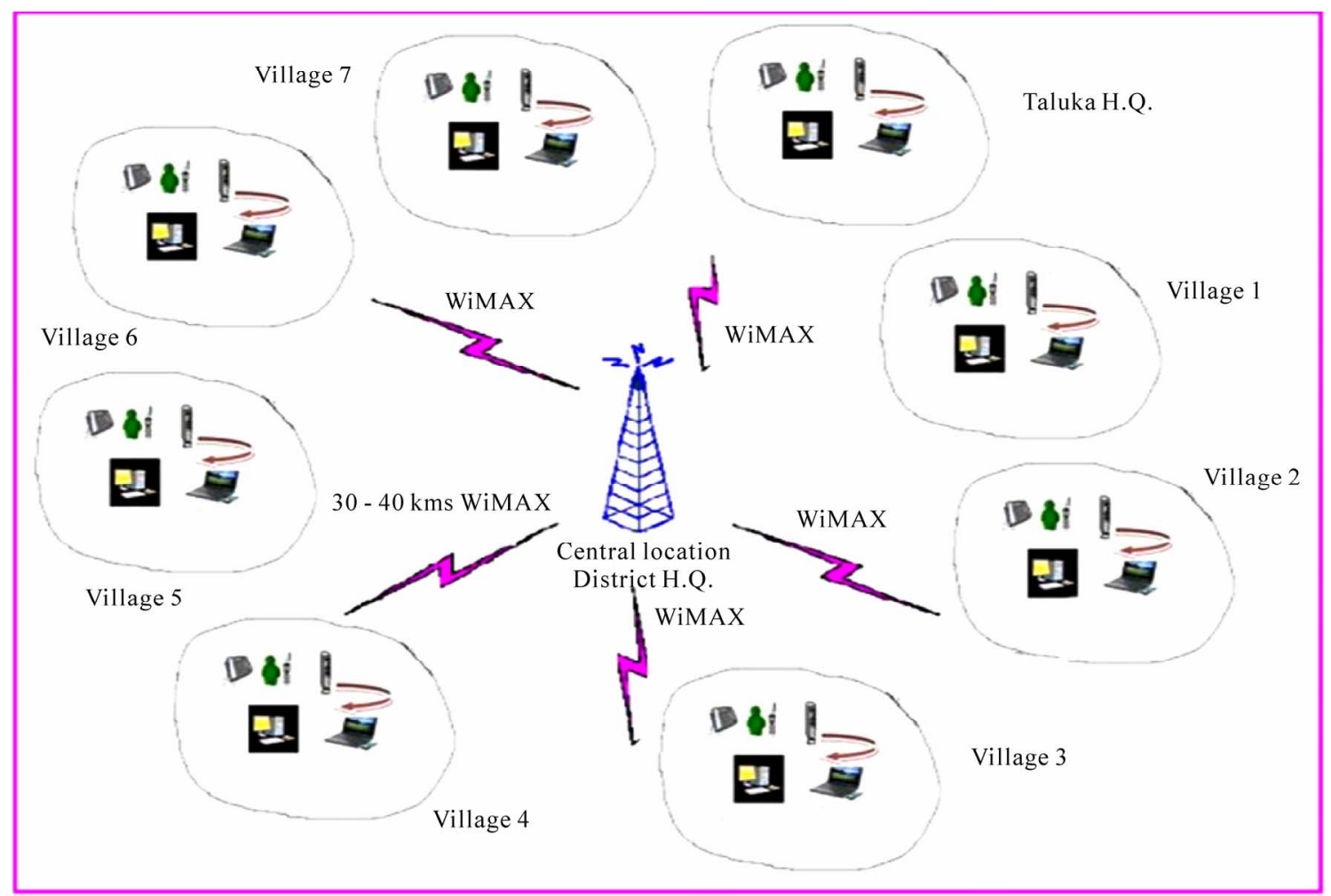

Figure 2. WiMAX model for Jalgoan district.

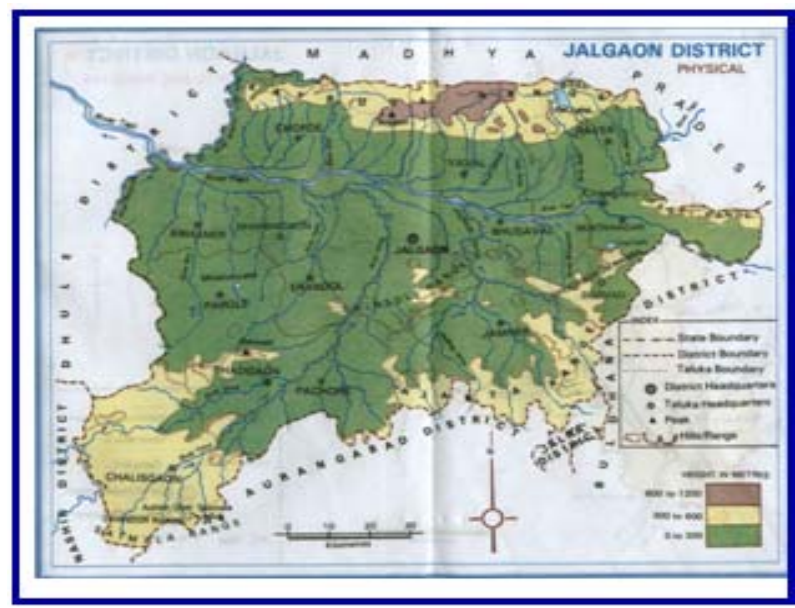

Figure 3. Jalgoan district map.

increase the economical growth of rural population, improve the living standard of rural populace, empower rural families with newly acquired knowledge and skills and make life secure and healthy. The local population would have to be made aware to willingly and enthusiastically use GKC functionality, ensuring the sustainability of the program. The local community would be trained to be able to run the WiMAX centres before the implementing agency moves to other regions. The GKCs, THQs and DHQ together should act as a rural library,

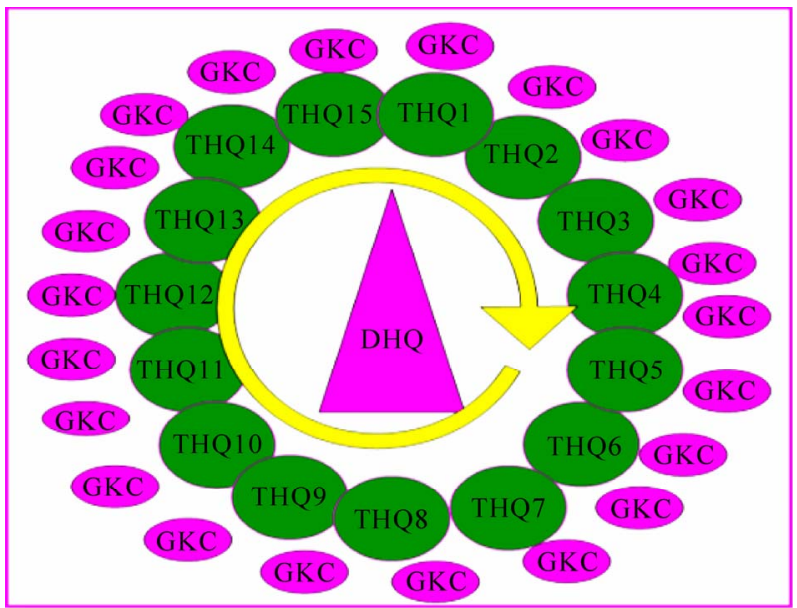

Figure 4. E-governance model for Jalgoan district.

Information centre, Public service facility centre, etc. Each THQ centre covers all villages within a radius of $50 \mathrm{~km}$ in the taluka. The centre will be equipped with PC/laptop computer, scanner, land-line phone connection, cell phone, web cameras, internet facility, a printer, a digital camera, solar power backup facility, etc. The GKC should be located in a public place. DHQ and Each THQ should promote two-way communication with GKC. With the help of this project, data-base will be created in regard to various records and taxes such as 
agriculture, Land/property, pets, houses, transfer of property, property tax, gender related record, literacy, birth and death record, marriage registration record etc. Through the WiMAX model rural women folk would be empowered and enlightened on various issues entailing women's rights and opportunities to be socially responsive and alleviate poverty. Administering Panchayat matters [births, deaths, utility connections (water, electricity etc.), property transfer, tax rules, all tax payments, license \& permits, Tourism and transport etc, booking of long distance Railway/bus travel etc is easily possible by involvement of the related service providers and the end users. Through wireless communication/video conference with experts in agriculture/public health, doctors/ veterinary doctors/counsellor, the rural people can seek help through the GKCs. It is also possible to provide information regarding individual vaccination schedule for pregnant women and infants, family planning, medicines, ambulance services and transportation, hospital and primary centre information, blood bank, life-saving drugs, doctors' database, appointment with doctors, tele-health, and hospital management system, to rural public health centre. For high speed data transfer and wireless broad band connectivity, WiMAX technology is convenient solution for e-governance in rural region.

\section{Simulation Setup}

OPNET MODELER is used for the simulation purpose. OPNET is a network technology development environment that allows design and study communication networks, devices, protocols and applications. In simple terms it allows to simulate elements of a computer network in order to investigate and how they will react to different circumstances without the need to physically construct them. OPNET MODELER is a highly versatile piece of software that is used for multiple purposes by a range of companies in both industry and research. One of its uses is in the design of computer networks. OPNET MODELER is used to test the suitability of the networks design. It offers ability to ensure that the networks design is capable of supporting the traffic and applications that would run on them. Simulation results are shown in Figures 6-8.

Steps involved in simulation of the scenario are given below.

1) Take scenario (network model) which is shown in Figure 5 and set the application which is to be examined.

2) Choose the number of subscribers and base station

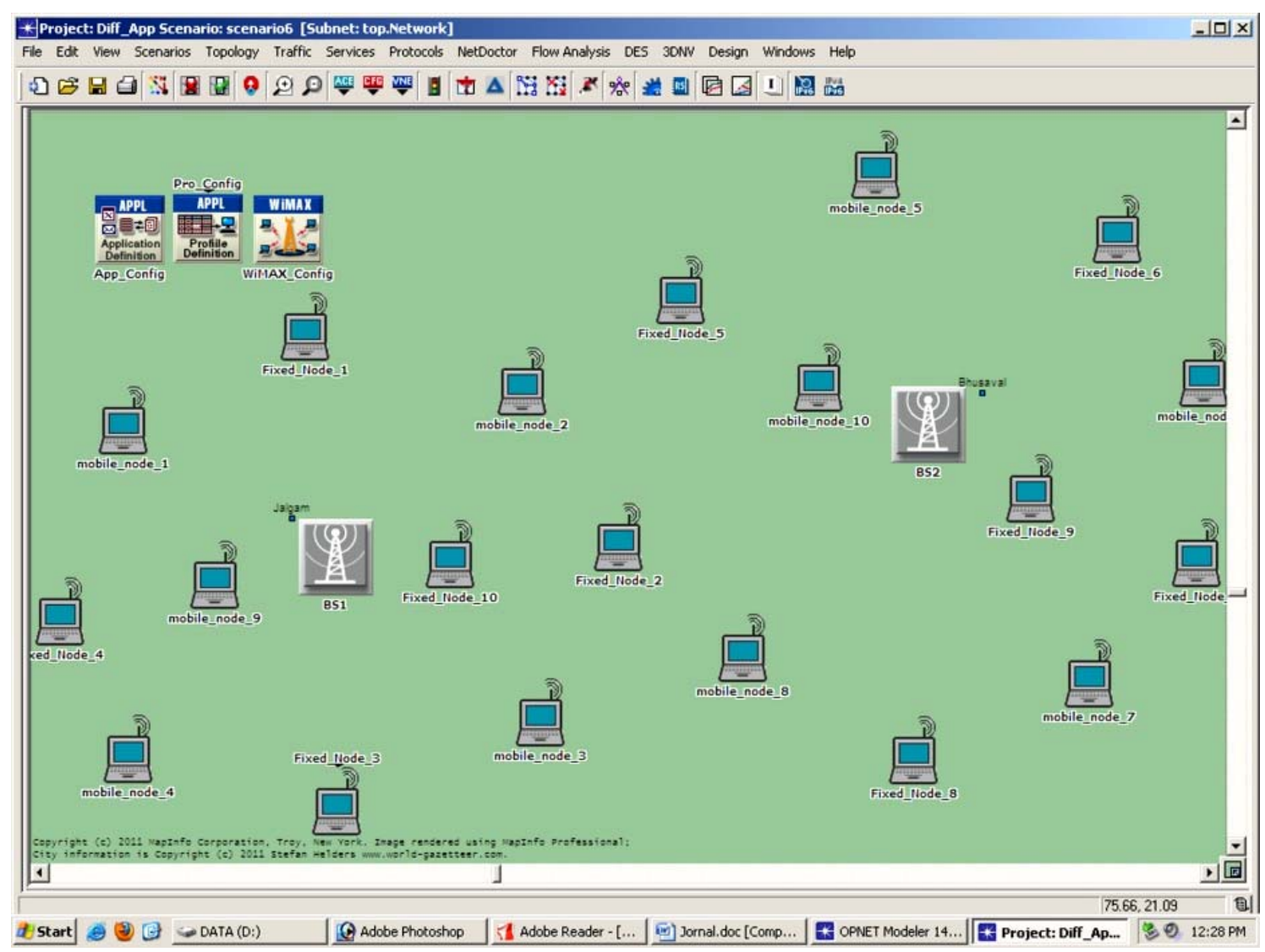

Figure 5. Network model. 


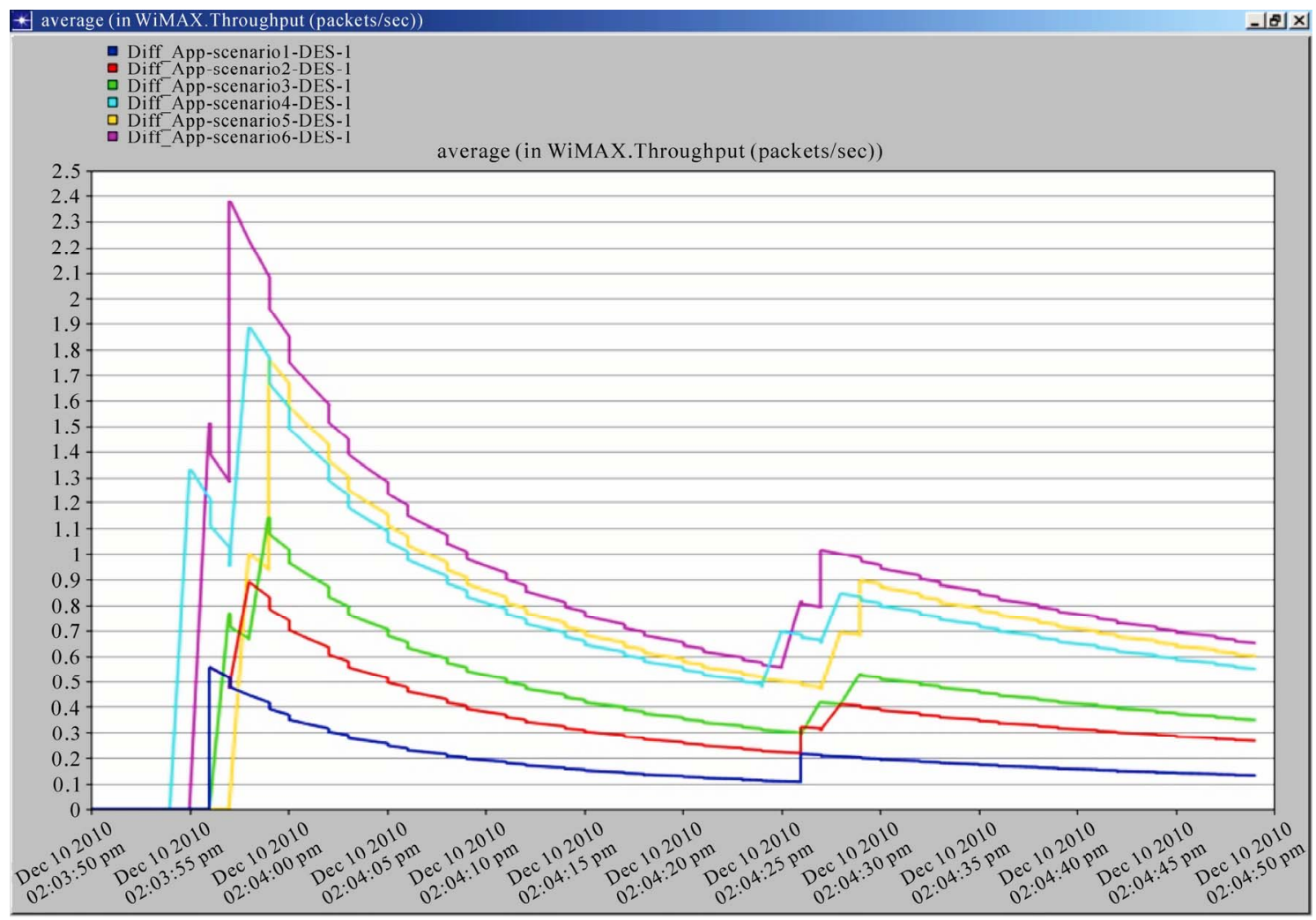

Figure 6 Throughput vs simulation time.

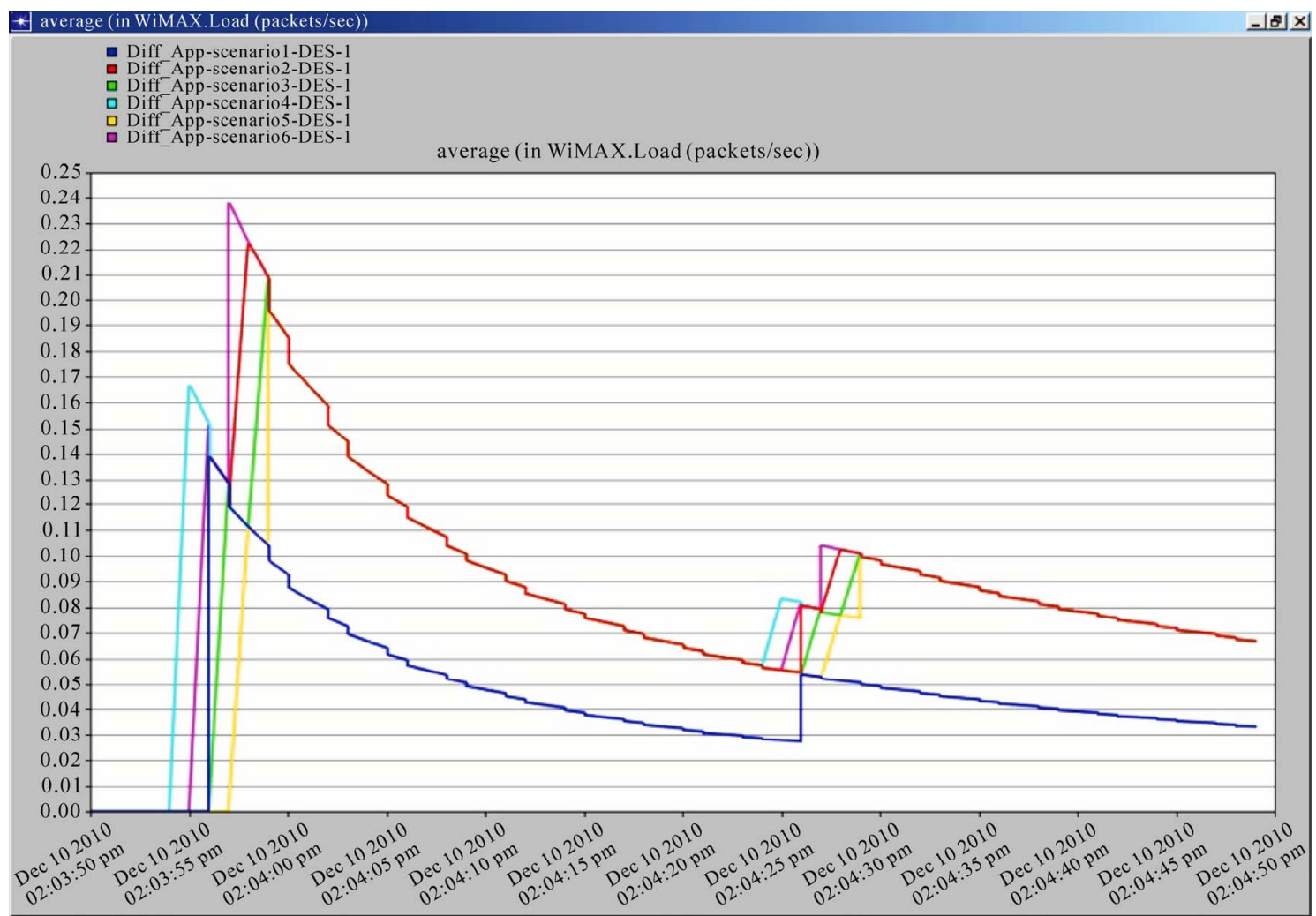

Figure 7. Load vs simulation time. 


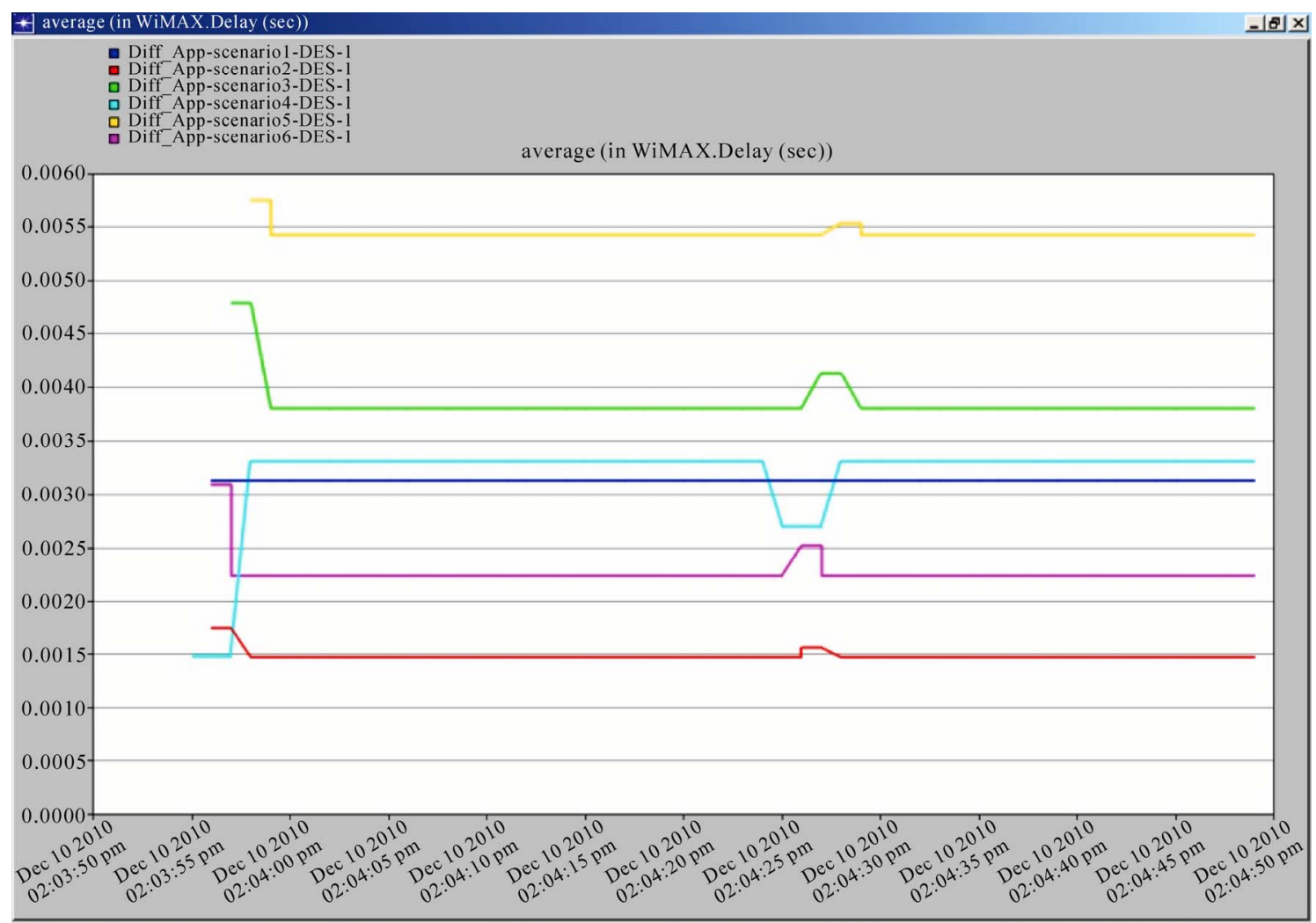

Figure 8. Delay vs simulation time.

and set their attributes according to application.

3) Set WiMAX attribute of all subscribers and base station and set symbol duration according to standard.

4) Set permutation mode as per the simulation criteria.

5) Simulate the scenario and observe the throughput and delay.

6) Create six scenarios and repeat the steps 1 to 4 .

7) Simulate the scenario and compare the throughput and delay result with previous result.

\section{Performance Analysis of Delay and Throughput}

In this research, we have divided our work into six different scenarios with the help of OPNET Modeler. In this paper we have made six scenarios. Here two types of MAC layer QoS are used and they are UGS and rtPS having application of Voice over IP (VoIP) and MPEG respectively. Also the traffic priority for UGS is high as compared to rtPS. In each scenario the number of fixed nodes (Fixed Subscriber Stations) and Mobile nodes (Mobile Subscriber Stations) are different. To cover more nodes or if nodes are outside the coverage area more than one BS are required. Through different scenario we have compare the throughput and delay with respect to time. The simulation parameters used in this model are listed in Table 4.
Table 4. Simulation parameters.

\begin{tabular}{lc}
\hline \multicolumn{1}{c}{ Efficiency Mode } & Mobility and Ranging Enabled \\
\hline $\begin{array}{l}\text { MAC Service Class } \\
\text { Definition (QOS) }\end{array}$ & 1) UGS \\
Eg. VOIP ( IP telephony) & 2) rtps \\
Eg. MPEG \\
(high rewsolution video) \\
Number of Subcarrirs \\
Wand Width
\end{tabular}

\section{Results}

Here the global analyses of all the scenarios are done and the comparison of throughput and delay are given. Here as the number of nodes increases the throughput of complete network will get improved since more number. Figure 6 shows the comparison of all six scenarios. Scenario 1 has the lowest throughput while scenario 6 has the highest throughput. Figure 7 Compares the load (packets/sec) throughout the network in each scenario. Here Scenario 1 has lowest load, scenarios 2, 3, 4, 5, 6 have somewhat same load for some period of time. Sce- 
nario 6 has the highest load at the initial stage. Figure 8 Compare the result between delay vs. Simulation time here we have seen that delay of scenario 2 is minimum and scenario 5 have maximum delay.

\section{Strength of WiMAX in Rural Area}

WiMAX shares Wi-Fi strength of not requiring expensive wires and cables and of allowing cheaper use of unlicensed spectrum. In addition to this, WiMAX provides additional range. Wi-Fi provides coverage of about $10 \mathrm{~km}$, but WiMAX offers a range of up to $50 \mathrm{~km}$. An increase in range is particularly important in the densely populated rural areas, since the number of people covered by a single tower is rather small compared to urban area. No matter what, having a tower and the range of the tower that increases the number of households served cuts down considerably on cost and would encourage service providers to establish themselves in rural areas. Just like Wi-Fi, WiMAX is an economically feasible option for rural India. However, the profits may not match that made in the urban areas. WiMAX also offers data transfer rates higher than 802.11a, 802.11b, and 802.11g, though not as high as the fastest Wi-Fi speed of 802.11n.

\section{Weakness of WiMAX in Rural Area}

Even though WiMAX is economically feasible, it is still potentially expensive to install and maintain with less than desirable payback in rural areas to keep service providers away from using it there. Even though WiMAX is better equipped for some rural parts in India than Wi-Fi, WiMAX is more expensive to install. Thus, even companies that were willing to provide wireless service to rural India, were not readily willing to spend the additional cost for installing WiMAX when they felt that Wi-Fi service was sufficient. Because of the cost of WiMAX, companies that possessed licensed spectrum are not very likely to make the investment in rural areas. Even though some unlicensed spectrum was still available for use in rural areas, much of the spectrum goes unused, causing even more limited service for rural areas. Use of unlicensed spectrum causes problems with collision responses and data loss that are not as prevalent with licensed spectrum.

\section{Limitations of WiMAX}

WiMAX is suitable technology for next generation with potential applications such as cellular backhaul, hotspot, VoIP mobiles and broadband connection, but it has some limitations as under.

1) Low bit rate over Long distance: WiMAX technology offers long distance data range of $50 \mathrm{~km}$ or 30 miles and high bit rate of $70 \mathrm{Mbps}$. That is fine, but both these features do not work together well. With the increase in the data distance/range, the bit rate reduces and vice versa.

2) Speed of connectivity: The WiMAX has other drawback that user closers to the tower can get high speed up to $30 \mathrm{Mbit} / \mathrm{s}$, but the users at the cell edge of the tower may obtain only up to $14 \mathrm{Mbit} / \mathrm{s}$ speed.

3) Sharing of bandwidth: In wireless technology, the bandwidth is shared by users in a specified radio sector. Therefore, functionality quality could go down if more than one user exists in a single sector.

4) Mostly users have a speed of 2 to 8 or $12 \mathrm{Mbit} / \mathrm{s}$. For better results, additional radio cards need to be added to the base station to boost the capability.

\section{Conclusions}

WiMAX is satisfactory solution for rural connectivity and it is a new standards-based wireless technology gaining rapid acceptance around the world. It is capable of delivering broadband Internet service and extending services like Internet telephony throughout India without major disruption to transportation and other services. Unlike wired solutions, it requires no blocking of traffic, no digging miles of trenches for laying telecommunication cables, no ruining blocks of roads to provide Internet services, no waiting on massive infrastructure build-out projects, and no overhanging cables that could snap anytime. WiMAX offers a fast, affordable, convenient solution to India's widespread Internet access required to start e-governance for rural administration, agriculture development and management and also for educational development. WiMAX delivers greater throughput and greater scalability to suit consumer's needs. WiMAX is suitable option for starting the e-governance at grass root level in rural area.

\section{REFERENCES}

[1] M. Backus, "E-Governance and Developing Countries," Research Report No. 3, April 2001, pp. 1-42. www.iicd.org/files/report3.doc

[2] Bharat Sanchar Nigam Limited (BSNL), "Urban and Rural Context, BSNL Services in Rural Area of West Bengal,” 2005, pp. 1-48.

[3] J. Howard, S. Charis and S. Erik, "What Works: NLOGUES Rural Connectivity Model,” A Digital Dividend Study by the World Resources Institute, July 2001, pp. 1-25.

[4] V. Kanugo, "Citizen Centric E-Governance in India, Strategies for Today, Vision for Future,” Chairman-SPEG, CMD-Internet Consortium India Private Limited, Paper 1 pp. 1-9.

www.docstoc.com/docs/26829379/e-governance-in-indian

[5] R. C. Gilbert, "The Changing Role of the Citizen in the 
E-Governance and E-Democracy Equation,” MA Law, Research Fellow, Common Wealth Centre for E-Governance, September 2003, pp. 1-111. www.tanzaniagateway.org

[6] M. S. S. Nathan, "Toolkit for Setting up Rural Knowledge Centre (RKC),” Research Foundation Report, 2004, pp. 1-20.

http://www.docstoc.com/docs/41746301/Rural-Knowledg e-Centres-insurance-knowledge

[7] Proxim Wireless, "Point to Multipoint WiMAX." http://www2.proxim.com/ptmpwimax.htm

[8] J. Codr and R. Jain, "Wireless Options for Providing Internet Services of Rural America," 2008, pp. 1-18. http://www.cse.wustl.edu/ jain/cse574-08/ftp/rural.pdf

[9] Technology@Intel Magazine, "WiMAX in India: Opening New Frontiers through Broadband Connectivity," January 2005.

http://www.cherlin.blogspot.com
[10] Electronics for You, "WiMAX Makes the Most Sense in Rural India,” March 2008, p. 157.

[11] J. G. Andrews, A. Ghosh and R. Muhamed, "Fundamentals of WiMAX Understanding Broadband Wireless Networking,” Prentice-Hall, Upper Saddle River, 2007.

[12] A. Lele, M. Raj and D. Das, "Providing Voice Connectivity to Rural India Using WiMAX: Issues and Solution,” 2009, pp. 1-6.

http://academic.research.microsoft.com/Paper/5502182

[13] M. Barbeau, "WiMAX/802.16 Threat Analysis," Proceedings of the 1st ACM International Workshop on Quality of Service Security in Wireless and Mobile Networks, Quebec, June 2005. http://portal.acm.org/citation.cfm?id=1089761.1089764

[14] Jalgaon District Information. http://cgwb.gov.in/District_Profile/Maharashtra/Jalgaon.p df 